\title{
VODNO NAČRTOVANJE IN NAČRTI UPRAVLJANJA VODA
}

\author{
dr. Aleš Bizjak \\ Inštitut za vode Republike Slovenije \\ Hajdrihova 28c, SI-I000 Ljubljana \\ e-mail: ales.bizjak@izvrs.si
}

\section{Strokovni članek}

COBISS 1.04

\section{Izvleček}

Direktiva 2000/60/ES - vodna direktiva - določa skupen evropski pristop k trajnostnemu upravljanju površinskih in podzemnih voda. Pri tem upošteva tako človekove vplive na vodno okolje kot tudi socioekonomske implikacije vplivov in predvidenih preventivnih in sanacijskih ukrepov. Okoljski cilj vodne direktive je doseči dobro stanje vseh voda na območju EU do leta 2015, s pogojnimi izjemami pa do leta 2021, oziroma najkasneje do leta 2027. Pri tem je temeljno izhodišče integralni vodnonačrtovalski pristop, t.j. integracija vseh dejavnikov vodnega okolja $\mathrm{v}$ načrte upravljanja voda ter informiranost in sodelovanje javnosti.

Ključne besede: vodna direktiva, integralno upravljanje voda, vodno načrtovanje, načrti upravljanja voda

\section{WATER PLANNING AND RIVER BASIN MANAGEMENT PLANS}

\begin{abstract}
Directive 2000/60/EC - Water framework directive - is a milestone in history of water policies in Europe. The Directive establishes a common framework for sustainable and integrated management of all European surface and groundwaters, taking into account all anthropogenic impact factors as well as economic implications of the preventive and sanitation measures. The ultimate objective of the Directive is to achieve good status of all waters in the EU member states by the year 2015, with exemptions by 2021 or latest by 2027 . The cornerstone of the Directive is the demand for integration and application of integrated water management approach through the river basin management plans as well as public participation and involvement.
\end{abstract}

Key words: Water framework directive, integrated water management, water planning, river basin management plan 
»Voda ni kot ostali tržni proizvodi, temveč je dediščina, ki jo je tako potrebno tudi varovati, braniti in obravnavati.« (Directive 2000/60/EC, Preambula (1))

\section{UVOD}

Direktiva 2000/60 Evropskega Sveta (Directive 2000/60/EC), v raziskovalnem in upravnem izrazoslovju vodna direktiva (ang. Water framework directive; v nadaljevanju: vodna direktiva), je postala veljavna 22. decembra 2000. Predvideva nov, integralen načrtovalski pristop k zaščiti, izboljšanju in trajnostni rabi vseh evropskih površinskih voda - rek, jezer, somornice in obalnega morja - ter podzemnih voda. Določa ambiciozen okoljski cilj skupne evropske politike do voda, to je dobro stanje vseh površinskih in podzemnih voda v državah članicah EU do leta 2015, z izjemami do leta 2021 oziroma najkasneje do leta 2027. Povzema tudi cilje in ukrepe vseh 'sestrskih' direktiv Evropskega sveta s področja voda ter z uporabo načrtov upravljanja voda (ang. River basin management plan; v nadaljevanju: NUV) in tvori integralen okvir za sodobno upravljanje voda. Republika Slovenija je leta 2002 v procesu prilagajanja zakonodaje države kandidatke EU z Zakonom o vodah (v nadaljevanju: ZV-1) in kasnejšimi pripadajočimi podzakonskimi akti, katerih del obravnava prispevek, povzela tudi vsa določila vodne direktive (Pravilnik o metodologiji za določanje vodnih teles podzemnih voda 2003; Pravilnik o metodologiji za določanje vodnih teles površinskih voda 2003; Pravilnik o določitvi vodnih teles podzemnih voda 2005; Pravilnik o določitvi in razvrstitvi vodnih teles površinskih voda 2005; Pravilnik o spremembah in dopolnitvah Pravilnika o določitvi in razvrstitvi vodnih teles površinskih voda 2006; Uredba o podrobnejši vsebini in načinu priprave načrta upravljanja voda 2006).

Vodna direktiva prinaša številne novosti v upravljanje voda, med katerimi so najpomembnejše: ekosistemski pristop, načrtovanje na ravni povodja oziroma porečja, uvajanje ekonomskih instrumentov in informiranost ter sodelovanje javnosti. Tako promovira nove, obsežnejše ekološke cilje zaščite kakovosti voda ter obnove strukture in funkcije akvatičnih ekosistemov. $\mathrm{V}$ pretekosti so bili cilji vodovarstva $\mathrm{v}$ evropskih državah predvsem zaščita voda pred onesnaženjem, s poudarkom na kemičnih in bioloških onesnaževalih, redkeje pa so obravnavali integralno kakovost vodnih ekosistemov. S hidrogeografskega vidika vodna direktiva določa porečja ali povodja kot osnovne upravljalsko-načrtovalske enote vodnega okolja za integralno upravljanje voda rek, jezer, obalnega morja in somornice ter podzemne vode. Tako zasnovana organizacija upravljanja in načrtovanja namreč omogoča pravilnejše in primernejše analize stroškov in koristi okoljskih ciljev ter stroškovno učinkovite kombinacije ukrepov za dosego okoljskih ciljev. Na področju ekonomskih instrumentov uvaja povračilo stroškov za rabo vode, umerjeno zaračunavanje cen storitev javnih služb, vzpodbujanje porabnikov k učinkovitejši rabi vode s primerno politiko cen vodnih storitev ter upoštevanje družbenih, okoljskih in ekonomskih učinkov povračila stroškov za rabo vode.

Hkrati vodna direktiva kot dokument sodobne načrtovalske doktrine določa sodelovanje deležnikov upravljanja voda ter vseh zainteresiranih javnosti in posameznikov na porečju ali povodju ali podobnih interesnih skupin iz sosednjih povodij in pripadajočih delov obalnih voda. 
V skladu z določili vodne direktive in ZV-1 ter Uredbe o podrobnejši vsebini in načinu priprave načrta upravljanja voda (v nadaljevanju: NUV) (2006) v Sloveniji izvajamo enoten vodnonačrtovalski proces, za vsako vodno območje (v nadaljevanju: VO) posebej. Tako nastajata NUV na VO Donave in NUV na VO Jadranskega morja.

V vodnonačrtovalskem procesu se uporabljajo nekateri pojmi, ki so specifični za področje dela vodnega načrtovanja ali pa so terminološka novost celo na evropski ravni. V nadaljevanju so podane razlage za nekatere najbolj bistvene ali pogoste pojme:

- integralno upravljanje voda (ang. integrated water management) je izvajanje vodnega načrtovanja, operacionalizacija programov stroškovno učinkovitih ukrepov ter izvajanje nadzora stanja v načrtovalskem obdobju na porečju ali povodju;

- vodno načrtovanje (ang. water planning) je iterativen proces izvajanja tehničnih analiz, to je zbiranja, analize, modeliranja in interpretacije podatkov o naravnih in antropogeno pogojenih procesih vodnega okolja $\mathrm{v}$ porečju ali povodju, ter oblikovanja programov stroškovno učinkovitih ukrepov in upravljanja na način, da bi dosegli cilje vodne direktive;

- načrt upravljanja voda (ang. river basin management plan) je dokument o upravljanju voda na vodnem območju, s poudarkom na stanju, ciljih in načrtovanih programih stroškovno učinkovitih ukrepov na vodnih telesih za doseganje ciljev upravljanja voda, s katerim mora biti seznanjena javnost;

- vodno telo (ang. water body) je osnovna upravljalska enota površinske ali podzemne vode, določena po enotni evropski metodi za določitev vodnih teles, na katerih so analizirani ekološki deficiti, določeni cilji, načrtovani in v kasnejšem delu načtovalskega obdobja aplicirani programi stroškovno učinkovitih ukrepov;

- pomembne zadeve upravljanja voda (ang. significiant water management issues) so tisti okoljski problemi vodnega okolja na porečju ali povodju, ki so bili z analizo verjetnosti doseganja okoljskih ciljev prepoznani kot razlogi, zaradi katerih vodna telesa kljub osnovnim ukrepom brez izvajanja dodatnih ukrepov ne bodo dosegla okoljskih ciljev vodne direktive ali sorodnih direktiv do zaključka prvega načrtovalskega obdobja leta 2015;

- program stroškovno učinkovitih ukrepov (ang. cost efficient programme of measures) je nabor osnovnih ukrepov iz seznama A in po potrebi stroškovno učinkovitih dopolnilnih ukrepov iz seznama B priloge VI vodne direktive oziroma 57. člena ZV-1, potrebnih za doseganje ciljev vodne direktive na vodnih telesih.

\section{NAMEN IN OKOLJSKI CILJI VODNE DIREKTIVE}

\section{I Namen vodne direktive}

Namen vodne direktive je določiti varstveni okvir za celinske površinske vode (vse stoječe ali tekoče vode na površju kopnega), somornice, obalno morje in podzemne vode, ki naj:

- preprečuje poslabšanje ali nadaljnje slabšanje stanja, oziroma varuje in izboljšuje stanje vodnih ekosistemov ter kopenskih ekosistemov in močvirij, ki so od vodnih ekosistemov neposredno odvisni;

- vzpodbuja trajnostno rabo vode; 
- s posebnimi ukrepi za zmanjševanje odvajanja, emisij in uhajanja prednostnih snovi poveča varstvo in izboljša stanje vodnega okolja;

- zagotovi postopno zmanjšanje onesnaženosti podzemne vode in prepreči nadaljnje onesnaževanje;

- prispeva $\mathrm{k}$ blažitvi posledic poplav in suš.

\subsection{Okoljski cilji vodne direktive}

Da bi bili doseženi nameni vodne direktive, ta določa okoljske cilje za površinske in podzemne vode, ki so zavezujoči za države države članice EU. Cilji na površinskih vodah so, da države članice:

- $\quad$ izvedejo ukrepe, s katerimi preprečijo poslabšanje stanja vseh teles površinske vode;

- varujejo, izboljšujejo in obnavljajo vsa telesa površinske vode, da se dobro stanje površinske vode doseže najkasneje leta 2015, z morebitnimi podaljšanji pa do leta 2021 oziroma najkasneje do leta 2027;

- varujejo in izboljšujejo vsa močno preoblikovana in umetna vodna telesa površinske vode, da se dober ekološki potencial in dobro kemijsko stanje površinske vode dosežeta najkasneje do leta 2015, z morebitnimi podaljšanji pa do leta 2021 oziroma najkasneje do leta 2027;

- $\quad$ izvajajo ukrepe za zmanjšanje onesnaževanja površinskih voda s prednostnimi snovmi in preprečevanje nadaljnjega onesnaževanja voda s prednostnimi nevarnimi snovmi.

Dobro stanje voda je določeno kot dobro kemijsko stanje in dobro ekološko stanje voda. Ekološko stanje voda temelji na bioloških, hidromorfoloških in fizikalno-kemijskih kakovostnih elementih. Izhaja iz referenčnih razmer - torej hipotetičnega stanja vodnega okolja brez človekovih vplivov - značilnih za tip vodnega telesa. Dober ekološki potencial je okoljski cilj, prilagojen posebni kategoriji vodnih teles. To so vodna telesa, ki so zaradi tehnoloških potreb po vodi, za katero je bila podeljena vodna pravica, hidromorfološko spremenjena, ter umetna vodna telesa, to so tista, ki so nastala kot posledica katerekoli človekove dejavnosti na območjih, kjer prej ni bilo površinske vode.

\subsection{Podaljšanje rokov za doseganje okoljskih ciljev}

Rok za doseganje okoljskih ciljev, leto 2015, se lahko podaljša za namene postopnega doseganja ciljev za vodna telesa do leta 2021 ali 2027, a le pod pogojem, da se stanje prizadetega vodnega telesa ne slabša več in četudi so izpolnjeni posebni pogoji, ki jih določa vodna direktiva: zahtevnost tehnične izvedljivosti, cena in nepredvidene naravne razmere.

\subsection{Manj strogi okoljski cilji}

Države članice si pri posameznih vodnih telesih lahko prizadevajo doseči manj stroge okoljske cilje od predpisanih, če so ta telesa zaradi človekovega delovanja tako prizadeta ali je njihovo naravno stanje tako, da bi bilo doseči te cilje tehnično neizvedljivo ali nesorazmerno drago, in če so izpolnjeni posebni pogoji, ki jih določa vodna direktiva. 
Slika 1: Določitev vodnih teles površinske vode (VTPV)

Figure 1: Delineation of surface water bodies

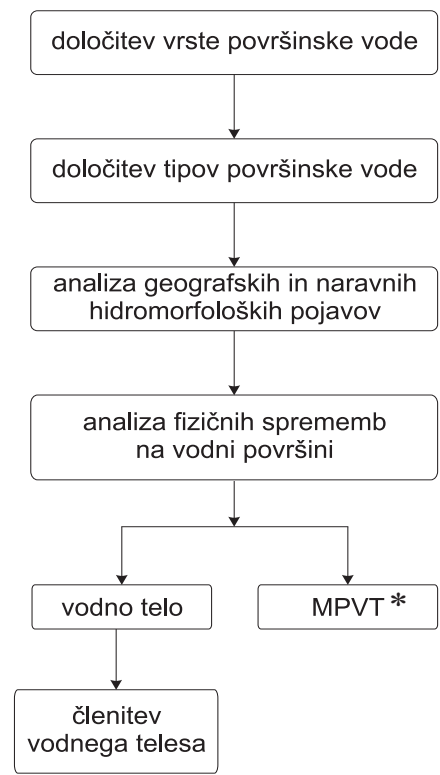

Vir/Source: Guidance document.... 2002

* Močno preoblikovano vodno telo

\section{INTEGRALNO UPRAVLJANJE VODNIH OBMOČlJ}

Integralnost je osrednji načrtovalski dejavnik za implementacijo ciljev vodne direktive. Ta jo predvideva z obveznim vključevanjem določil, ciljev in zahtev direktiv, navedenih v prilogi VI v načrtovalski postopek in posledično v načrte upravljanja voda. Dejavnik integralnosti upravljanja vodnih območij je upoštevan tudi $v$ številnih drugih vidikih načrtovanja:

- integralno opredeljen okoljski cilj - dobro stanje voda - ki upošteva kemijsko, biološko, fizikalno-kemijsko in hidromorfološko stanje voda;

- $\quad$ skrb za vse površinske - reke, jezera, somornico in obalno morje - ter podzemne vode;

- razumevanje površinskih in podzemnih ter celinskih in obalnih voda kot enotnih vodnih ekosistemov;

- obravnavanje treh načrtovalskih kategorij voda, vodnih teles, umetnih vodnih teles in močno preoblikovanih vodnih teles;

- $\quad$ vzpostavitev integralnega nadzora nad spremljanjem kemijskega in ekološkega stanja površinskih voda - nadzorno, obratovalno in preiskovalno spremljanje stanja - ter kemijskega in količinskega stanja podzemnih voda;

- vključevanje celotne evropske in nacionalne zakonodaje s področja voda; 
- določitev časovnih horizontov za potrebe izvajanja tehničnih analiz (izhodiščni scenarij ali napoved stanja leta 2015) in izvajanja načrtovanja (leta 2015, 2021 in 2027);

- uporaba ponovljive metode DPSIR (driver - gonilna sila, pressure - pritisk, state - stanje, impact - vplivi, response - ukrep) za določitev sanacijskih ukrepov od vira vplivov dalje;

- aplikacija kombinacij osnovnih, dopolnilnih in dodatnih ukrepov za doseganje okoljskih ciljev vodne direktive;

- $\quad$ integriranje ciljev, zahtev in ukrepov, predvidenih na območjih s posebnimi zahtevami v načrtovalski proces;

- integrirano načrtovanje in upravljanje voda na ravneh vodno telo - porečje ali povodje vodno območje;

- vključevanje vseh z upravljanjem voda povezanih sektorjev ter zagotavljanje interdisciplinarnosti;

- informiranje, vključevanje in aktivno sodelovanje javnosti pri vseh analizah odločitev vodnega načrtovanja;

- upoštevanje socio-ekonomskih dejavnikov upravljanja voda pri določanju programov ukrepov - ekonomske cene vode, analize stroškovne učinkovitosti, analize stroškov in koristi;

- upoštevanje prekomejnega konteksta površinskih in podzemnih voda ter iskanja skupnih prekomejnih sanacijskih in preventivnih ukrepov za doseganje ciljev vodne direktive;

- upoštevanje dejavnika podnebnih sprememb na način preveritve klimatske odpornosti predvidenih sanacijskih ukrepov za doseganje ciljev vodne direktive.

\section{MEDSEKTORSKO POVEZOVANJE}

Temeljno načelo kateregakoli sodobnega načrtovanja je povezanost vsebin in upoštevanje sektorjev in drugih dejavnikov, ki lahko vpivajo na vsebine in cilje načrtovanja. Zaradi specifičnega medija in ciljev vodnega načrtovanja je to še toliko večjega pomena, saj je upravljanje voda ali vodnega okolja dejavnost, ki privlači tako razvojno kot okoljsko usmerjene sektorje. Vodno načrtovanje na ravni porečij in povodij je torej gorišče koordinacije državnih sektorskih politik za vidike upravljanja voda.

Temeljita medsektorska koordinacija na ravni porečij in povodijje predpogoj za učinkovito implementacijo vodne direktive. Po njenih določilih morajo države članice zagotoviti polno vključevanje načrtov upravljanja voda in vodne politike v vse ključne gospodarske sektorje in njihove politike, npr. v kmetijstvo, energetiko, promet, turizem, poselitev, regionalni razvoj, politiko varstva pred naravnimi in drugimi nesrečami itd. Pri tem je seveda treba zagotoviti tudi pristojnosti in pravno moč odgovornih teles ter sredstva za uresničevanje ciljev vodne direktive.

V proces priprave NUV na vodnih območjih je prav tako treba vključiti sektorje in organizacije s področja upravljanja voda, varstva okolja in ohranjanja narave, ter vse druge sektorje in organizacije, ki lahko z aktivnostmi pospešijo ali zavirajo doseganje ciljev načrta upravljanja voda.

Zaradi potreb doseganja okoljskih ciljev lahko integracija poteka na geografsko različnih območjih. Na ravni porečja ali povodja se lahko npr. izvaja proces integracije med ukrepi za 
zmanjševanje izpostavljenosti poplavam, vodooskrbo in ukrepi varstva narave. Na nacionalni ravni se proces integracije izvaja npr. na zakonodajnem področju, med zakonskimi določili s področja voda in zakonskimi določili ostalih sektorjev. Na ravni EU pa lahko proces integracije razumemo kot usklajevanja politik, npr. vodne, poplavne, kmetijske, energetske, naravovarstvene itd.

\section{EVROPSKI NAČRTOVALSKI PRISTOP NA PODROČJU VODA}

\section{I Pripravljalno obdobje in načrtovalska obdobja}

Načrtovalski pristop, predviden z vodno direktivo, členimo na pripravljalno načrtovalsko obdobje od sprejema direktive leta 2000 do začetka prvega načrtovalskega obdobja leta 2009, ter tri šestletna načrtovalska obdobja 2009-2015, 2015-2021 in 2021-2027 kot zadnjim načrtovalskim horizontom vodne direktive, ko naj bi bili dokončno doseženi okoljski cilji na vseh površinskih in podzemnih vodah EU. V vseh treh načrtovalskih obdobjih so osnovni elementi načrtovanja (slika 2):

- presoja vplivov na vodnih območjih;

- nadzor stanja;

- določitev okoljskih ciljev;

- izdelava in implementacija programov stroškovno učinkovitih ukrepov (v nadaljevanju: programi ukrepov) za doseganje okoljskih ciljev vodne direktive in ciljev sorodnih direktiv.

Slika 2: Šestletni načrtovalski cikel in koncept DPSIR

Figure 2: Six-year planning cycle and the DPSIR concept

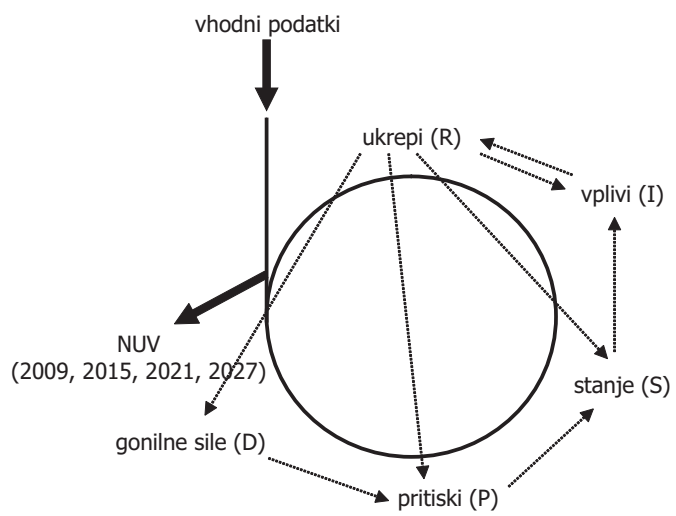

\subsection{Tehnične analize in analize odločitev vodnega načrtovanja}

Pripravljalno načrtovalsko obdobje je namenjeno določitvi načrtovalskih podlag - odgovorne uprave za načrtovanje, geografske opredelitve vodnih območij, mednarodne povezave, t.j. vsebin, združenih v Nacionalnem poročilu o izvajanju vodne direktive v letu 2003 (2004) 
ter izvedbi tehničnih analiz za potrebe načrtovanja - vodna telesa površinskih in podzemnih voda, analiza obremenitev in vplivov, ocena verjetnosti doseganja okoljskih ciljev na vodnih telesih, ekonomske analize cene vode, to je vsebin, združenih v Nacionalnem poročilu o izvajanju vodne direktive v letu 2004 (2005).

V zaključnem delu pripravljalnega obdobja se izvedejo analize odločitev za izdelavo osnutka prvega načrta upravljanja voda na vodnem območju, to so pomembne zadeve upravljanja voda ter priprava osnutkov programov ukrepov. V pripravljalnem obdobju poteka tudi obveščanje, posvetovanje in priporočeno aktivno sodelovanje javnosti, ki jih vodna direktiva predvideva kot sestavni del sodobnega upravljanja voda.

Pomembni novosti, ki ju prinaša evropska doktrina vodnega načrtovanja, sta metoda DPSIR (slika 2) ter analiza stroškov in koristi ukrepov. Metoda DPSIR je ponovljiv in transparenten postopek določanja stanja vodnih teles. Glede na načelo 'onesnaževalec plača', ki je eno vodilnih vodne direktive, metodološki pristop predvideva tudi določitev vira (npr. sektorja), od koder izvira pritisk na vodno okolje.

\subsection{Območja načrtovanja}

Vodno načrtovanje se izvaja na območjih različnih velikostnih redov, od vodnega telesa, porečja ali povodja do vodnega območja. Manjše kot je območje načrtovanja, podrobnejše načrtovalske analize so predvidene (preglednica 1).

Preglednica 1: Območja načrtovanja tehničnih analiz in analiz odločitev

Table 1: Areas of planning in technical analysis and decision analysis

\begin{tabular}{|c|c|c|c|c|}
\hline & leto obdelave & vodna telesa & porečje/povodje & vodno območje \\
\hline \multicolumn{5}{|l|}{ tehnične analize } \\
\hline poročilo po čl. $3 \mathrm{VD}$ & 2004 & & & + \\
\hline poročilo po čl. $5 \mathrm{VD}$ & 2005 & + & + & \\
\hline OVDOC* & 2006 & + & & \\
\hline ekonomske analize & 2008 & + & & \\
\hline \multicolumn{5}{|l|}{ analize odločitev } \\
\hline PZUV** & 2007 & & + & \\
\hline PSUU*** & 2008 & + & & \\
\hline
\end{tabular}

*ocena verjetnosti doseganja okoljskih ciljev

**pomembne zadeve upravljanja voda

*** program stroškovno učinkovitih ukrepov

\section{POMEMBNE ZADEVE UPRAVLJANJA VODA}

Pomembne zadeve upravljanja voda je tehnični izraz za okoljske probleme vodnega okolja na porečju ali povodju, ki so bili z analizo verjetnosti doseganja okoljskih ciljev prepoznani kot razlogi, zaradi katerih vodna telesa kljub že izvedenim osnovnim ukrepom iz seznama A priloge VI vodne direktive, in brez izvedbe dodatnih ukrepov (seznam B priloge VI vodne 
direktive) ne bodo dosegla okoljskih ciljev vodne direktive ali sorodnih direktiv do zaključka prvega načrtovalskega obdobja leta 2015.

Pomembne zadeve upravljanja voda se določajo na ravni porečij ali povodij v skladu s prepoznano problematiko raziskovanega porečja ali povodja, izhajajočo iz predhodno izdelane ocene verjetnosti doseganja okoljskih ciljev. Običajno so to problemi zaradi organskega onesnaženja in onesnaženja s hranili, prednostnimi snovmi in onesnaževali, izhajajoči iz točkovnih in razpršenih virov onesnaževanja vodnega okolja, problemi zaradi hidroloških in morfoloških obremenitev (fizične modifikacije vodnega okolja) ali problemi zaradi vnosov tujerodnih vrst (biološke obremenitve vodnega okolja). Kot načrtovalsko stopnjo pa lahko pomembne zadeve upravljanja voda predstavimo tudi kot iskanje odgovorov na vprašanja:

- Kaj so problemi vodnega okolja?

- Kdo ali kaj jih povzroča?

- Kolikšne deficite upravljanja voda povzročajo?

Pomembne zadeve upravljanja voda na porečju ali povodju so metodološko izhodišče za določitev programov ukrepov na vodnih telesih porečja ali povodja (slika 3).

\section{PROGRAMI UKREPOV}

Določitev programov ukrepov je osrednja odločitvena stopnja vodnega načrtovanja pred izdelavo NUV (slika 3). Izhaja neposredno iz načrtovalske stopnje pomembne zadeve upravljanja voda na ravni porečja ali povodja ter iz okoljskih ciljev. Ti temeljijo na tehnični in ekonomski presoji ukrepov, določenih za vsako vodno telo vodnega območja. Programi ukrepov se določajo za vsako vodno telo, glede na predhodno ugotovljeno okoljsko problematiko (preglednica 1). V vodnem načrtovanju na ravni vodnega območja je ukrep običajno pragmatična akcija (npr. pravni red, finančno orodje, prostovoljni dogovor ali sporazum itd.), potrebna za premostitev prepoznanih ekoloških deficitov vodnih teles in pravočasnega doseganja zadanih okoljski ciljev, zato običajno manjkrat neposredno vodi v akcijo na terenu. Vodna direktiva kategorizira osnovne, dopolnilne in dodatne ukrepe za potrebe doseganja okoljskih ciljev vodnih teles.

Program ukrepov metodološko izhaja iz generičnih seznamov ukrepov, v končni obliki pa vsebuje katalog ukrepov z navedbo možnega financiranja ukrepov. Ukrepi se določajo posebej za vsak sektor, ki je bil v predhodnih analizah prepoznan kot povzročitelj obremenitev vodnega okolja, in vsebujejo ključne dejavnosti za doseganje okoljskih ciljev.

Osnutek programa ukrepov mora biti objavljen in dan na vpogled javnosti z možnostjo komentarjev leta 2008, v dokončni obliki leta 2009, izvedljivi do leta 2012, pregledajo in po potrebi dopolnijo pa se ob začetku drugega načrtovalskega obdobja leta 2015, nato pa vsakih šest let. Kot načrtovalsko stopnjo lahko opredelitev programov ukrepov predstavimo tudi kot iskanje odgovorov na vprašanja:

- Kaj že počnemo, da bi prepoznane probleme odpravili?

- Kaj še lahko storimo, da bi stanje voda še izboljšali?

- Kolikšni so stroški preventivnih in sanacijskih ukrepov?

- Kdo je vpleten v proces izboljšanja stanja vodnega okolja? 


\section{I Osnovni ukrepi}

Osnovni ukrepi so ukrepi, ki se povzamejo po nacionalni zakonodaji države članice in morajo biti vsaj skladni z ukrepi navedenimi v členu 11.3 vodne direktive ter v direktivah, navedenih v delu A priloge VI vodne direktive (preglednica 2).

Preglednica 2: Direktive iz vodne direktive, priloga VI, del A

Table 2: Directives listed in Annex VI, part A, Water framework directive

- $\quad$ Direktiva o kopalnih vodah (76/160/EGS), Direktiva o kopalnih vodah (76/160/EGS), nadomeščena z Direktivo o upravljanju kakovosti kopalnih voda (2006/7/ES);

- $\quad$ Ptičja direktiva (79/409/EGS);

- $\quad$ Direktiva o pitni vodi (80/778/EGS), spremenjena z Direktivo (98/83/ES);

- $\quad$ Direktiva o večjih nesrečah (Seveso) (96/82/ES);

- Direktiva o presoji vplivov na okolje (85/337/EGS);

- Direktiva o blatu iz čistilnih naprav (86/278/EGS);

- Direktiva o čiščenju komunalne odpadne vode (91/271/EGS);

- Direktiva o fitofarmacevtskih sredstvih (91/414/EGS);

- $\quad$ Nitratna direktiva (91/676/EGS);

- $\quad$ Habitatna direktiva (92/43/EGS);

- Direktiva o celovitem preprečevanju in nadzorovanju onesnaževanja (96/61/ES).

Vir/Source: Directive 2000/60/EC

\subsection{Dopolnilni ukrepi}

Dopolnilni ukrepi so ukrepi, ki se oblikujejo in izvajajo kot dopolnilo osnovnim ukrepom, v kolikor tehnične analize pokažejo, da slednji ne bodo zadostovali za doseganje okoljskih ciljev vodnih teles v skladu z zahtevami vodne direktive. Navedeni so v delu B priloge VI vodne direktive (preglednica 3).

Preglednica 3: Dopolnilni ukrepi iz vodne direktive, priloga VI, del B Table 3: Additional measures, annex VI, part B, Water framework directive

- $\quad$ pravni instrumenti;

- upravni instrumenti;

- $\quad$ gospodarski ali davčni instrumenti;

- $\quad$ pogajanja o okoljskih sporazumih;

- ukrepi nadzorovanja emisij;

- $\quad$ kodeksi dobre prakse;

- $\quad$ ponovna vzpostavitev in obnova močvirij;

- $\quad$ nadzor nad odvzemanjem;

- ukrepi usmerjanja povpraševanja, med drugim vzpodbujanje prilagojene kmetijske proizvodnje, kot je pridelovanje poljščin, ki potrebujejo malo vode na sušnih območjih;

- $\quad$ ukrepi za gospodarnost in ponovno uporabo, med drugim vzpodbujanje tehnologij z učinkovito rabo vode $\mathrm{v}$ industriji in $\mathrm{z}$ vodo varčnih metod namakanja;

- $\quad$ gradbeni projekti; 
- $\quad$ razsoljevalni obrati;

- $\quad$ projekti rehabilitacije;

- umetno obnavljanje vodonosnikov;

- $\quad$ izobraževalni projekti;

- $\quad$ raziskovalni, razvojni in predstavitveni projekti;

- drugi ukrepi.

Vir/Source: Directive 2000/60/EC

Slika 3: Pomembne zadeve upravljanja voda in programi ukrepov v vodnem načrtovanju Figure 3: Significant water management issues and programmes of measures in water planning

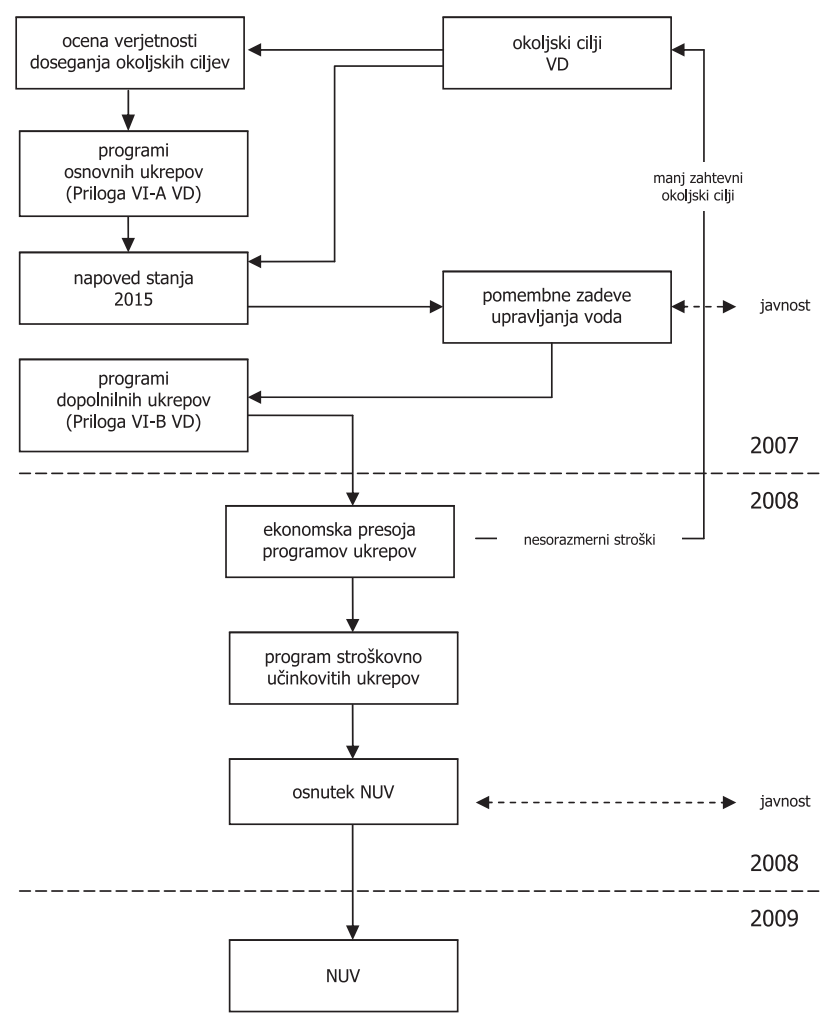

\subsection{Dodatni ukrepi}

Dodatni ukrepi so ukrepi, ki se oblikujejo in izvajajo le v primeru, kadar spremljanje stanja ali drugi podatki kažejo, da okoljski cilji vodne direktive na vodnem telesu ne bodo doseženi kljub izvedenim osnovnim in dopolnilnim ukrepom. Dodatni ukrepi se po potrebi navedejo šele $\mathrm{v}$ prvi ali v nadaljnjih posodobitvah načrta upravljanja voda. 


\section{NAČRTI UPRAVLJANJA VODA}

\section{I Poslanstvo NUV}

Integralno upravljanje voda, kot ena od upravljalskih kategorij trajnostnega razvoja družbe, razvija ukrepe na področju varstva kakovosti voda in vodnih ekosistemov, ukrepe za zagotavljanje človekovih potreb po vodi kot biološki, okoljski, ekonomsko-utilitarni in socialni kakovosti ter ukrepe za zmanjševanje izpostavljenosti človeških življenj in lastnine delovanju vodnih procesov. Poslanstvo NUV kot osrednjega dokumenta vodnega načrtovanja je zato beleženje rezultatov tehničnih analiz, določitev glavnih ciljev, določitev preventivnih in sanacijskih ukrepov za izboljšanje stanja, ocena stroškov upravljanja voda na vodnem območju v načrtovalskem obdobju ter informiranje javnosti o stanju vodnega okolja na vodnem območju. Poslanstvo NUV je na ta način tudi povečanje uspešnosti in gotovosti upravljanja voda na vodnem območju v prihodnje.

\subsection{Namen NUV}

Načrt upravljanja voda je osrednji dokument načrtovalskega cikla in rezultat sukcesivnih stopenj vodnega načrtovanja, ki jih povzema: opis vodnega območja, tehnične analize, pomembne zadeve upravljanja voda in programi ukrepov (preglednica 4). Pri tem velja izhodišče, da si vodno načrtovanje prizadeva zaščititi in izboljšati vodno ter širše okolje z uvajanjem trajnostnega upravljanja $\mathrm{z}$ vodnimi viri ter da je, kot vsako drugo načrtovanje, iterativen proces. Prav tako velja tudi izhodišče, da morajo biti v proces izdelave NUV vključene skupine deležnikov na vodnem območju: uprave sektorjev, javni zavodi, strokovne institucije, raziskovalne ustanove, lokalna samouprava, nevladne organizacije, posamezniki in ostali deležniki, določeni v načrtovanju. Na podlagi naštetih osnovnih izhodišč se lahko uspešno realizira namen NUV, ki je:

- $\quad$ predstaviti cilje upravljanja voda na vodnih telesih v vodnem območju;

- predstaviti programe stroškovno učinkovitih ukrepov za doseganje ciljev upravljanja voda;

- opredeliti vsebine operativnega upravljanja voda na vodnem območju;

- posredovati strateške načrtovalske usmeritve na področju vodnega načrtovanja na vodnem območju;

- posredovati usmeritve za integracije planov in politik z vplivom na stanje vode;

- poročati o rezultatih vodnega načrtovanja, obveščanja, vključevanja in morebitnega aktivnega sodelovanja javnosti v načrtovanju v načrtovalskem obdobju na vodnem območju;

- pripraviti vsebine za poročanje Evropski komisiji o procesu implementacije vodne direktive.

\subsection{Cilj NUV}

Cilj NUV je s stroškovno učinkovitimi programi ukrepov nasloviti v načrtovanju prepoznane pomembne zadeve upravljanja voda na vodnem območju ter cilje upravljanja voda na vodnih telesih in informirati javnost o naštetih vsebinah. 
Preglednica 4: Vsebine načrtov upravljanja voda

Table 4: Content of the river basin management plan

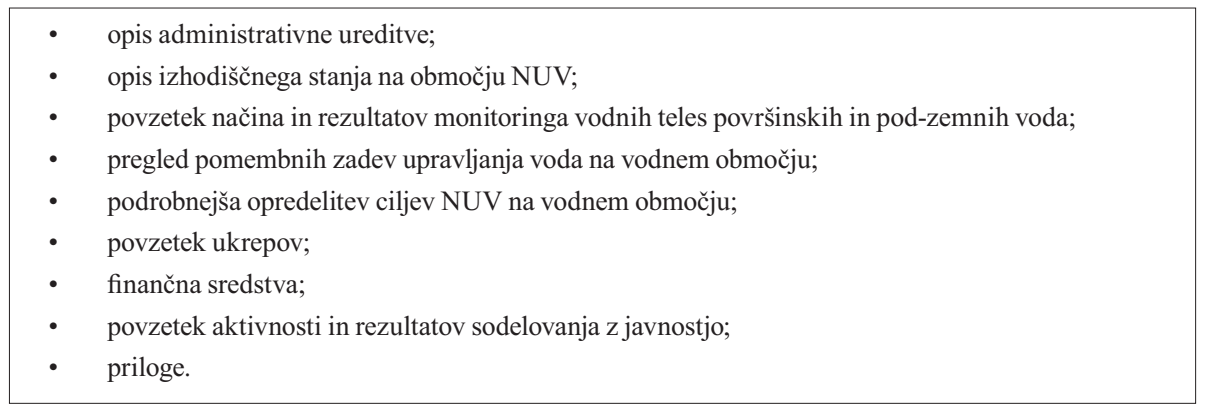

Vir/Source: Pravilnik o spremembah in dopolnitvah Pravilnika o določitvi in razvrstitvi vodnih teles površinskih voda 2006

\section{VODNO NAČRTOVANJE V SLOVENIJI}

V Sloveniji se je s sprejemom Zakona o vodah (2002), ki je povzel vsebine in določila vodne direktive, začel intenzivno odvijati tudi proces vodnega načrtovanja na vodnem območju Donave in vodnem območju Jadranskega morja, ki ga na strokovni ravni koordinira Inštitut za vode Republike Slovenije. Izhodišče načrtovanja je prva določitev vodnih teles površinskih voda (Pravilnik o določitvi in razvrstitvi vodnih teles površinskih voda 2005; Pravilnik o spremembah in dopolnitvah Pravilnika o določitvi in razvrstitvi vodnih teles površinskih voda 2006; slika 4) in podzemnih voda (Pravilnik o določitvi vodnih teles podzemnih voda 2005) ki sta jo v skladu z evropskim postopkom določanja vodnih teles izdelala Inštitut za vode Republike Slovenije in Geološki zavod Slovenije (preglednica 5).

\section{I Zakonodajni okvir}

Zakonodajni in operativni okvir vodnega načrtovanja in integralnega upravljanja voda v Sloveniji tvorijo:

- Zakon o varstvu okolja (2004);

- Zakon o vodah (2002; Zakon o spremembah in dopolnitvah Zakona o vodah 2008);

- podzakonski akti s področja upravljanja voda;

- Nacionalni program upravljanja voda;

- operativni programi s področja upravljanja voda.

Zakon o varstvu okolja (2004) je na področju upravljanja voda podal pravne podlage za:

- določitev standardov kakovosti;

- izvajanje spremljanja stanja voda;

- klasifikacijo stanja voda;

- $\quad$ podlage za pripravo operativnih programov: izvajanja direktive o odvajanju in čiščenju komunalnih odpadnih voda, izvajanja nitratne direktive in zmanjšanja vnosa nevarnih snovi v vodno okolje. 
Zakon o vodah (2002; Zakon o spremembah in dopolnitvah Zakona o vodah 2008) pa je podal pravne podlage za izvajanje vodne politike:

- teritorialne osnove;

- večnivojski sistem načrtovanja na vodnih območjih (NUV) ter na podrobnejših merilih in temah (podrobnejši NUV);

- podrobnejša vsebina načrtov;

- terminski načrt za pripravo in dopolnitve načrtov upravljanja voda;

- cilje in izjeme za doseganje ciljev upravljanja voda;

- podlage za varstvo kopalnih voda, varstvo virov pitne vode, varstvo vodovarstvenih območij ter varstvo voda za življenje rib in školjk.

\subsection{Institucionalna organiziranost}

Koordinacijo priprave strokovnih podlag in strokovnih vsebin poglavij NUV na vodnem območju Donave in NUV na vodnem območju Jadranskega morja zagotavlja Ministrstvo za okolje in prostor.

Pripravo strokovnih podlag ter strokovnih vsebin poglavij NUV na vodnem območju Donave in NUV na vodnem območju Jadranskega morja na podlagi razpoložljivih uradnih podatkovnih baz Agencije Republike Slovenije za okolje zagotavlja Inštitut za vode Republike Slovenije (v nadaljevanju: IzVRS) s sodelovanjem strokovnih institucij: Geološki zavod Slovenije (v nadaljevanju: GeoZS), Nacionalni inštitut za biologijo - Morska biološka postaja Piran ter Zavod za ribištvo Republike Slovenije.

\subsection{Priprava načrtov upravljanja voda}

IzVRS in GeoZS sta v skladu s časovnico vodne direktive in določili Delovnega programa za NUV na vodnem območju Donave (2007) in Delovnega programa za pripravo NUV na vodnem območju Jadranskega morja (2007) izdelala strokovne podlage za potrebe poročanja, Republika Slovenija pa je po pravni in upravni uskladitvi strokovnih podlag Evropski komisiji do sedaj posredovala poročila, javnosti pa omogočila vpogled v njih:

- Nacionalno poročilo o izvajanju vodne direktive v letu 2003;

- Nacionalno poročilo o izvajanju vodne direktive v letu 2004 - vodno območje Donave;

- Nacionalno poročilo o izvajanju vodne direktive v letu 2004 - vodno območje Jadranskega morja;

- Vmesno poročilo o poteku priprave načrta upravljanja voda na vodnem območju Donave. Pomembne zadeve upravljanja voda;

- Vmesno poročilo o poteku priprave načrta upravljanja voda na vodnem območju Jadranskega morja. Pomembne zadeve upravljanja voda.

IzVRS in GeoZS sta v letu 2007 izdelala strokovne podlage za predzadnjega od pripravljalnih korakov za prvo načrtovalsko obdobje od 2009 do 2015, to so strokovne podlage za potrebe določitve PZUV. Strokovne podlage so zapisane v ločenih poročilih za vodni območji Donave in Jadranskega morja, vsakokrat ločeno za površinske in podzemne vode 
(Pomembne zadeve upravljanja voda - površinske vode 2007; Pomembne zadeve upravljanja voda - podzemne vode 2007).

Slika 4: Vodna območja, porečja, povodja in vodna telesa $v$ Sloveniji

Figure 4: River basin districts, river basins and surface water bodies in Slovenia

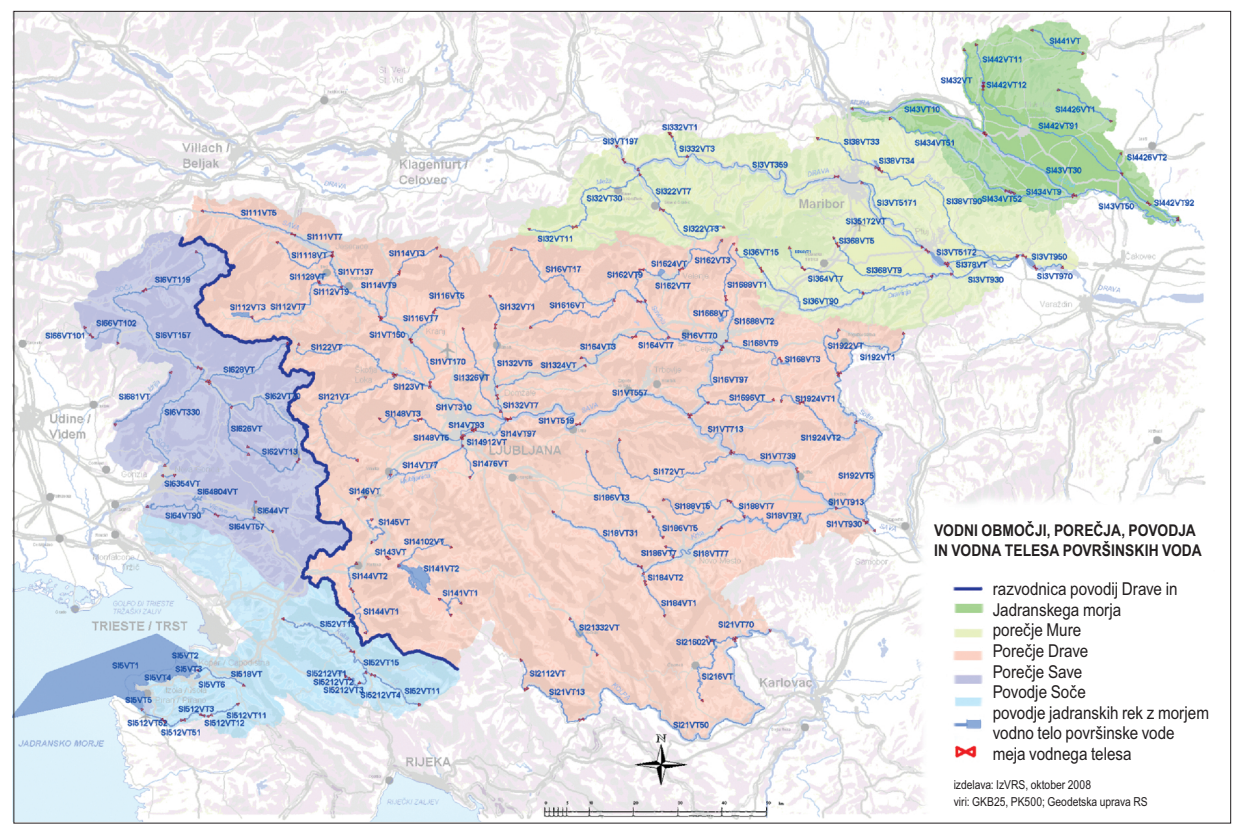

Preglednica 5: Vodna telesa površinskih voda v Sloveniji

Table 5: Surface water bodies in Slovenia

\begin{tabular}{|l|c|c|c|c|c|c|c|c|}
\hline & Mura & Drava & Sava & $\begin{array}{c}\text { VO } \\
\text { Donave }\end{array}$ & Soča & $\begin{array}{c}\text { Jadranske } \\
\text { reke }\end{array}$ & $\begin{array}{c}\text { VO Jadr. } \\
\text { morja }\end{array}$ & Skupaj \\
\hline VTPV* reke & 14 & 24 & 80 & 118 & 15 & 13 & 30 & 146 \\
\hline VTPV jezera & 0 & 0 & 3 & 3 & 0 & 0 & 0 & 3 \\
\hline $\begin{array}{l}\text { VTPV } \\
\text { somornice }\end{array}$ & 0 & 0 & 0 & 0 & 0 & 0 & 0 & 0 \\
\hline $\begin{array}{l}\text { VTPV } \\
\text { obalno morje }\end{array}$ & 0 & 0 & 0 & 0 & 0 & 6 & 6 & 6 \\
\hline Skupaj & $\mathbf{2 4}$ & $\mathbf{2 4}$ & $\mathbf{8 3}$ & $\mathbf{1 2 1}$ & $\mathbf{1 5}$ & $\mathbf{1 9}$ & $\mathbf{3 4}$ & $\mathbf{1 5 5}$ \\
\hline VTPV & 14 & 14 & 75 & 101 & 13 & 15 & 28 & 129 \\
\hline UVT** & 2 & 2 & 2 & 4 & 0 & 0 & 0 & 4 \\
\hline kMPVT*** & 8 & 8 & 6 & 16 & 2 & 4 & 6 & 22 \\
\hline Skupaj & $\mathbf{2 4}$ & $\mathbf{2 4}$ & $\mathbf{8 3}$ & $\mathbf{1 2 1}$ & $\mathbf{1 5}$ & $\mathbf{1 9}$ & $\mathbf{3 4}$ & $\mathbf{1 5 5}$ \\
\hline
\end{tabular}

* vodna telesa površinskih voda, ** umetno vodno telo *** kandidat za močno preoblikovano vodno telo 


\subsection{Sodelovanje strokovne javnosti v delovnih procesih IzVRS}

Z namenom verifikacije strokovnih podlag osnutka NUV, izvajata IzVRS in GeoZS aktivnosti posvetovanj s strokovno javnostjo na porečjih, podporečjih in povodjih slovenske hidrografske mreže. Predlog strokovnih podlag za potrebe izdelave študije PZUV je bil strokovni javnosti predstavljen in dan $\mathrm{v}$ strokovno presojo na delavnici Problematika vodnega okolja na porečjih in povodjih, ki jo je IzVRS organiziral v Ljubljani septembra 2007. Na delavnici so bile predstavljene metodološke vsebine in strokovni predlogi PZUV na porečjih, podporečjih in povodjih - porečje Save je bilo zaradi obsežnosti in lažje obdelave razdeljeno na podporečja Savinja ter zgornja, srednja in spodnja Sava (Aktivnosti in rezultati posvetovanja ... 2007).

Kot drugi korak v procesu informiranja, sodelovanja in posvetovanja s strokovno javnostjo, je IzVRS s sodelovanjem GeoZS za potrebe verifikacije strokovnih predlogov programov ukrepov izvedel v letu 2008 osem posvetovanj s strokovno javnostjo na porečjih, podporečjih in povodjih - ponovno je bilo porečje Save zaradi obsežnosti in lažje obdelave razdeljeno na podporečja Savinja ter zgornja, srednja in spodnja Sava.

V nadaljevanju procesa priprave NUV na vodnih območjih Donave in Jadranskega morja IzVRS s sodelovanjem GeoZS načrtuje v letu 2009 izvedbo aktivnosti posvetovanj na strokovni ravni z upravljalci hidroenergetske in vodne infrastrukture po porečjih, podporečjih in povodjih, to je $\mathrm{z}$ deležniki na močno preoblikovanih vodnih telesih. Aktivnosti posvetovanja bodo pripravljene $\mathrm{v}$ okviru procesa priprave strokovnega predloga programov ukrepov.

\section{I0. NAČRTOVALSKI IZZIVI PRIHODNOSTI}

\section{I0.I Nadaljnja načrtovalska opravila}

Članice EU so pred največjim in najtežjim izzivom vodnega načrtovanja, to je pred določitvijo programov ukrepov. Ti naj v načrtovalskem obdobju do leta 2015, s tehnično in finančno argumentiranimi izjemami pa do leta 2021 oziroma najkasneje do leta 2027, prispevajo k doseganju okoljskih ciljev na tistih vodnih telesih, za katere smo v predhodnih načrtovalskih stopnjah s tehničnimi analizami ugotovili, da ne bodo ali verjetno ne bodo dosegla okoljskih ciljev. Pri tem je pomembna ugotovitev, da je konsistentnost načrtovalske stopnje določitve programov ukrepov odvisna od doslednosti predhodnih načrtovalskih opravil, kakovost aplikacije programov ukrepov pa od pravne, upravne in seveda finančne kondicije države članice.

Povzetke programov ukrepov morajo države članice objaviti v osnutkih NUV na vodnih območjih na javnosti dostopen način do konca leta 2008. Javnost bo imela nato šest mesecev časa za posredovanje pripomb, hkrati pa bo morala pristojna uprava posredovati primerne odgovore javnosti. Leto dni po objavi osnutkov mora pristojna uprava objaviti NUV na vodnih območjih za prvo načrtovalsko obdobje od 2009 do 2015. Naslednja pomembna letnica v agendi načrtovalskega procesa vodne direktive je leto 2013, ko bodo morali postati ukrepi iz NUV operativni. 


\subsection{Obveščanje, sodelovanje in aktivno vključevanje javnosti}

Pristojne institucije upravljanja voda $v$ državah članicah morajo s primernimi strategijami komuniciranja z javnostmi neprestano povečevati osveščenost javnosti. Potrebne so jasne dolgoročne usmeritve na področjih obveščanja, sodelovanja in v zrelejših obdobjih načrtovanja tudi aktivnega vključevanja javnosti. Pri tem je velikega pomena usposabljanje in vključevanje nevladnih organizacij kot dodatnega komunikacijskega člena med upravo in prebivalstvom držav.

\subsection{Ključni izzivi vodne direktive in projektne tesni}

Ključni izzivi vodne direktive, kot so kohezivna vodna zakonodaja, okoljski cilji, doseganje dobrega ekološkega stanja na stroškovno najbolj učinkovit način, transparentno odločanje, interakcije med sektorji, ki uporabljajo vodo in interakcije med politiki, oblastmi, privatnim sektorjem ter civilno družbo, zahtevajo večslojno in optimalno pripravljenost družbe. Ob tem velja poudariti, da bo zahtevnost vsebin vodne direktive prežela pravne, upravne, institucionalne, izobraževalne, socialne in ekonomske vidike tudi najbolj naprednih in pripravljenih evropskih družb.

Zato se je potrebno zavedati tudi projektnih tesni, ki lahko zavirajo že tako zahteven proces implementacije vsebin vodne direktive in integracije ciljev v vse razvojne sektorske načrte družbe. Pri tem so velikega pomena vsaj:

- razpoložljivost, usposobljenost in raven občutka pripadnosti človeških virov uprave in javnih institucij;

- razpoložljivost, primernost, dostopnost in stanje podatkovnih baz;

- raven osveščenosti širše javnosti o splošnem pomenu vode;

- raven osveščenosti širše in institucionalne javnosti ter sektorskih javnosti o vsebinah in pomenu implementacije vodne direktive;

- $\quad$ sindrom NIMET (ang. Not In My Electoral Term) v primeru potrebe po ukrepih načrtovanja, neljubih za uprave razvojnih sektorjev ali občinske uprave.

\section{I. SKLEP}

Vodna direktiva z uvajanjem trajnostnih principov upravljanja voda, ekosistemskega pristopa, koncepta integralnosti in sodelovanja javnosti prispeva k številnim za človeka in vodno okolje nadvse pomembnim vrednotam in dejavnostim, kot so:

- zagotavljanje zadostnih zalog kakovostne površinske in podzemne vode, ki so potrebne za trajnostno, uravnoteženo in pravično rabo vode;

- zmanjšanje onesnaževanja površinskih in podzemnih vod ter preprečevanje odvečnega modificiranja vodnih ekosistemov na ekonomsko preverjen način;

- varstvo celinskih voda in obalnih morij;

- uresničevanje ciljev mednarodnih sporazumov na področju varstva okolja.

Da bi evropska družba v za to določenem času dosegla v prispevku omenjene vseobsegajoče cilje vodne direktive, slednja predvideva tudi zelo strnjeno časovnico izvajanja vodno- 
načrtovalskega procesa po naprej predvidenih sukcesivnih načrtovalskih stopnjah. Glede na dosedanje izkušnje lahko ugotovimo, da sta znanje in finančna moč družbe tista dejavnika, ki bosta $v$ prihodnje zagotovo najbolj vplivala na uspešnost implementacije določil vodne direktive in razvoj predvidenega načrtovalskega procesa.

Za potrebe uspešnosti tehničnih analiz, kar neposredno vpliva na pravilnost odločevalcev v kasnejših stopnjah načrtovanja, predvsem $v$ povezavi z določevanje programov ukrepov, je nujno potrebno poglabljati znanja metodologij, kabinetnih in terenskih raziskovalnih tehnik, obvladovanja podatkovnih baz in njihovih povezav ter modeliranj procesov v vodnem okolju v povezavi z GIS orodji. Razvijati je potrebno tudi znanja in tehnike s področja informiranja, sodelovanja in aktivnega vključevanja strokovne in širše javnosti, kot so delavnice, strokovna posvetovanja, panelne diskusije, okrogle mize, delavnice, obvestila za javnost itd. Ob tem je nujno potrebno opozoriti na usposabljanje nevladnih organizacij za potrebe zagotavljanja aktivne in učinkovite vloge civilne družbe v načrtovalskem procesu.

Za uspešno implementacijo določil vodne direktive bo razen znanj in splošne družbene osveščenosti o pomenu vode seveda potrebno zagotoviti tudi dovolj finančnih sredstev za izvajanje programov dela in drugih delovnih obveznosti. Prve ocene stroškov implementacije vodne in 'sestrskih' direktiv v nekaterih evropskih državah opozarjajo na zelo visoke številke - po domačih analizah je ocena stroškov implementacije le osnovnih ukrepov vodne direktive v Sloveniji do leta 2017 8,4 mrd. $€$ do leta 2015 (Cilji in ukrepi na vodnih telesih površinskih voda - VO Donave 2008; Cilji in ukrepi na vodnih telesih površinskih voda VO Jadranskega morja 2008), ki jih bodo predvsem revnejše države jugovzhodnega dela EU težje krile. Če upoštevamo še stroške implementacije določil poplavne direktive in trenutno globalno gospodarsko krizo, bo na področju financiranja implementacije vodne direktive verjetno potrebno še marsikaj doreči tako na evropski kot na nacionalnih ravneh.

\section{Viri in literatura}

Aktivnosti in rezultati posvetovanja $\mathrm{z}$ déležniki pri pripravi strokovnih podlag o pomembnih zadevah upravljanja voda. Poročilo. Inštitut za vode RS. Ljubljana 2007.

Cilji in ukrepi na vodnih telesih površinskih voda - VO Donave. Tekstualni del in priloge. Inštitut za vode RS. Ljubljana 2008.

Cilji in ukrepi na vodnih telesih površinskih voda - VO Jadranskega morja. Tekstualni del in priloge. Inštitut za vode RS. Ljubljana 2008.

Delovni program za pripravo načrta upravljanja voda na vodnem območju Donave. Ministrstvo za okolje in prostor. Ljubljana 2007. Medmrežje: http://www.mop.gov.si.

Delovni program za pripravo načrta upravljanja voda na vodnem območju Jadranskega morja. Ministrstvo za okolje in prostor. Ljubljana 2007. Medmrežje: http://www.mop. gov.si.

Directive 2000/60/EC of the European Parliament and the Council of 23 October 2000 establishing a framework for Community action in the field of water policy. Official journal of the European Communities, 327 (22. 12. 2000). Bruselj 2000.

Guidance document on identification and designation of heavily modified and artificial water bodies. CIS WG 2.2 (december 2002). CIS (Community information system) 2002. 
Identification of water bodies. Horizontal guidance document on the application of the term 'water body' in the context of the Water framework directive. CIS (Community information system) 2003.

Nacionalno poročilo o izvajanju vodne direktive v letu 2003. Ministrstvo za okolje in prostor. Ljubljana 2004. Medmrežje: http://www.mop.gov.si.

Nacionalno poročilo o izvajanju vodne direktive v letu 2004 - VO Donave. Ministrstvo za okolje in prostor. Ljubljana 2005. Medmrežje: http://www.mop.gov.si.

Nacionalno poročilo o izvajanju vodne direktive v letu 2004 - VO Jadranskega morja. Ministrstvo za okolje in prostor. Ljubljana 2005. Medmrežje: http://www.mop.gov.si.

Pomembne zadeve upravljanja voda - podzemne vode. Tekstualni in kartografski del. Geološki zavod Slovenije. Ljubljana 2007.

Pomembne zadeve upravljanja voda - površinske vode. Tekstualni in kartografski del. Inštitut za vode RS. Ljubljana 2007.

Pravilnik o določitvi in razvrstitvi vodnih teles površinskih voda. Uradni list RS 63/2005. Ljubljana.

Pravilnik o določitvi vodnih teles podzemnih voda. Uradni list RS 63/2005. Ljubljana.

Pravilnik o metodologiji za določanje vodnih teles podzemnih voda. Uradni list RS 65/2003. Ljubljana.

Pravilnik o metodologiji za določanje vodnih teles površinskih voda. Uradni list RS 65/2003. Ljubljana.

Pravilnik o spremembah in dopolnitvah Pravilnika o določitvi in razvrstitvi vodnih teles površinskih voda. Uradni list RS 26/2006. Ljubljana.

Strokovne podlage za načrt upravljanja voda na VO Donave. 8 zvezkov. Inštitut za vode RS in Geološki zavod Slovenije. Ljubljana 2008.

Strokovne podlage za načrt upravljanja voda na VO Jadranskega morja. 8 zvezkov. Inštitut za vode RS in Geološki zavod Slovenije. Ljubljana 2008.

Uredba o podrobnejši vsebini in načinu priprave načrta upravljanja voda. Uradni list RS 26/2006. Ljubljana.

Vmesno poročilo o poteku priprave načrta upravljanja voda na vodnem območju Donave. Pomembne zadeve upravljanja voda. Ministrstvo za okolje in prostor, Ljubljana 2008. Medmrežje: http://www.mop.gov.si.

Vmesno poročilo o poteku priprave načrta upravljanja voda na vodnem območju Jadranskega morja. Pomembne zadeve upravljanja voda. Ministrstvo za okolje in prostor. Ljubljana 2008. Medmrežje: http://www.mop.gov.si

Zakon o spremembah in dopolnitvah Zakona o vodah (ZV-1A). Uradni list RS 57/2008. Ljubljana.

Zakon o varstvu okolja. Uradni list RS 41/2004. Ljubljana.

Zakon o vodah (ZV-1). Uradni list RS 67/2002. Ljubljana. 


\section{WATER PLANNING AND RIVER BASIN MANAGEMENT PLANS}

\section{Summary}

»Water is not a commercial product like any other but, rather, a heritage which must be protected, defended and treated as such.« (Directive 2000/60/EC, Preamble (1))

Directive 2000/60/EC (Water Framework Directive; hereinafter: WFD) establishes a new, integrated planning approach to protection, improvement and sustainable use of all European surface waters - rivers, lakes, transitional waters and coastal waters, as well as groundwaters. It provides the ambitious goal of a common European water policy - to achieve good status of all surface waters and groundwaters until 2015, with exemptions until 2021 or 2027 at the latest. WFD considers all other water-related directives, listed in Annex VI, Part A (see Table 2), and promotes River Basin Management Plan (hereinafter: RBMP) as a planning tool of contemporary integrated water management. In the EU accession process the Republic of Slovenia has transposed the WFD with the adoption of Water Law (2002) and a series of water-related ordinances and regulations. The integration of planning aspects, sectors and other factors is the basic principle of any contemporary planning, which can potentially influence the planning contents and goals. In this manner, an integrative approach is the core planning factor in the WFD implementation process also. Therein it is understood as the obligatory integration of requirements and goals of directives listed in the WFD Annex VI, Part A (see Table 2) in the planning process and consequently in the RBMPs.

The WFD planning approach is divided into a preparation phase, from the adoption of the WFD to the beginning of the first RBM cycle in 2009, followed by three six-year planning cycles, 2009-2015, 2015-2021 and 2021-2027. The key planning elements in the three cycles are: impact assessment, determination of significant water management issues, monitoring, setting of environmental goals and setting and implementation of cost-efficient programmes of measures - basic (see Table 2), additional (see Table 3) and supplementary measures (see Fig. 3). A significant invention of the WFD planning process is the DPSIR analysis tool (driver - pressure - state - impact - response; see Fig. 2), which ensures a transparent and robust tracing of the sources of pressures to the water environment. Another important invention is the economic analysis of costs and benefits of the proposed programme of measures.

Integrated water management is one of the core sustainable development categories of the modern society. It provides the measures of water quality and water ecosystem protection, to ensure the fulfillment of human needs for water as a biological, ecological, economic and social quality, as well as measures to decrease the exposure of human life and property to water processes. In this way, the mission of the RBMP, as the key document of the planning process, is the recording of the results of technical analyses, setting the goals and determination of preventive and sanitary measures for improvement of water status, and assessment of water management costs in the planning area (see Table 1) and period.

Due to the characteristics and the mission of the RBMP as a focal planning document in water management, several groups of stakeholders must be included into the preparation of the RBMP: authorities, administrations, sectors, public, professional and research institutions, local governments, broad public, individuals and other stakeholders, as defined in the planning process. 
The goal of the RBMP is to address significant water management issues, record specific environmental goals and programme of measures on water bodies, and to inform the public about important issues of the water management process.

The purpose of the RBMP is to introduce the goals of water management on water bodies in the planning area, to present programmes of cost efficient measures to achieve the goals, to set contents of operational water management and strategic planning directions in the area of planning, to communicate the directions for integration of policies, plans and programmes into the water management, to report on the results of water planning and participatory processes and to prepare the contents for the purposes of reporting to the European Commission (see Table 4).

In the Republic of Slovenia, two river basin districts were delineated by the Water Law (2002): the Danube River Basin District, consisting of the Mura, Drava and Sava river basins, and the Adriatic Sea River Basin District, consisting of the Soča and Adriatic Rivers river basins (see Fig. 4). Consequently, two RBMPs are under preparation. The competent authority and coordinating body for the preparation of RBMPs in Slovenia is the Ministry of the Environment and Spatial Planning. The starting point for the planning process is the first delineation of water bodies (see Fig. 1 and 4; see Table 5), prepared by the Institute for Water of the Republic of Slovenia and the Geological Survey of Slovenia. The preparation of background planning documents and coordination of research institutes taking part in the planning process is ensured by the Institute for Water of the Republic of Slovenia. Other institutions contributing to the RBMPs in Slovenia are: the Geological Survey of Slovenia, the National Institute of Biology, the Marine Biology Station and the Fisheries Research Institute of Slovenia.

EU member states are now facing the biggest challenge since the beginning of the WFD planning process - establishment and application of a cost-efficient programme of measures to achieve the WFD environmental goals on water bodies. The programmes of measures must be set until 2009 within the RBMPs and become operational in 2012. Environmental goals must be achieved until the end of the first planning period, that is, until 2015. Exemptions are possible only upon providing detailed technical and financial reasons for extending the dates until 2021 and 2027, respectively.

In addition, other key WFD challenges, like cohesive water policies, environmental goals, good status of waters, transparent decision making, interactions among sectors, politicians, authorities, private sector and civil society, demand a multilayered and optimal condition of the society. The complexity of the WFD process will pervade legal, institutional, educational, social and economic directions of all European communities. Clear and long-term solutions related to public information, participation and, in later stages, active involvement are needed.

In order to implement successfully the WFD provisions, beside the in-depth knowledge on a broad spectrum of water issues as well as high level of social awareness on the importance of the water as an ecological, economical and social limiting factor, a considerable amount of financial resources will have to be ensured, as up-to-date cost assessments already show. Taking into account the implementation of the new directives, like Flood Directive, and global economy crisis, many water management financial issues will have to be communicated both on European and national levels. 